\title{
Decoding antibacterial and antibiofilm properties of cinnamon and cardamom essential oils: a combined molecular docking and experimental study
}

\author{
Elahe Pourkhosravani ${ }^{1}$, Fatemeh Dehghan Nayeri ${ }^{1^{*}}$ (]) and Mitra Mohammadi Bazargani ${ }^{2^{*}}$
}

\begin{abstract}
This study sets out to compare the antibacterial and antibiofilm profiles of $\mathrm{Ci} / \mathrm{Ca}$ EOs alone and in combination together against infectious bacterial strains. MIC assay was carried out to survey the effectiveness of prepared EOs by two-fold serial dilution method and MTT evaluation. Synergic antibacterial properties of EOs against target strains were studied by using checkerboard titration method. Biofilm growth and development were evaluated using CV and XTT reduction assays. Antibacterial activity was observed for EOs against both bacterial strains with stronger activity for CiEO against both bacteria. The synergistic antibacterial effect was observed only against B. subtilis. Based on the FIC index, combinations could not inhibit the growth of E. coli. The pure EOs and their combination inhibited cell attachment for both studied bacteria with stronger effect on E. coli. CV and XTT reduction assays results showed that $\mathrm{Ci}$ EO and its combination with CaEO had the highest antibiofilm activity at lowest MIC value $0.08 \%$ and $0.04 / 0.02 \%$ against biofilm formed by E. coli and B. subtilis respectively, indicating a high antibiofilm potential. Computational docking analyses also postulated that the active constituents of evaluated EOs have the potential to interact with different bacterial targets, suggested binding mode of action of EOs metabolites. By and large, synergistic anti-biofilm properties of EOs may provide further options for developing novel formula to inhibit a variety of infectious clinical and industrial strains without (or less) toxicity effects on human body.
\end{abstract}

Keywords: Antibiofilm, Bacteria, Cinnamomum verum, Elettaria cardamomum, Essential oil

\footnotetext{
*Correspondence: nayeri@eng.ikiu.ac.ir; bazargani@irost.ir

1 Agricultural Biotechnology Department, Faculty of Agriculture

and Natural Sciences, Imam Khomeini International University (IKIU),

Qazvin, Iran

${ }^{2}$ Medicinal Plant Department, Agriculture Institute (ARI), Iranian Research

Organization for Science and Technology (IROST), Tehran, Iran
} 


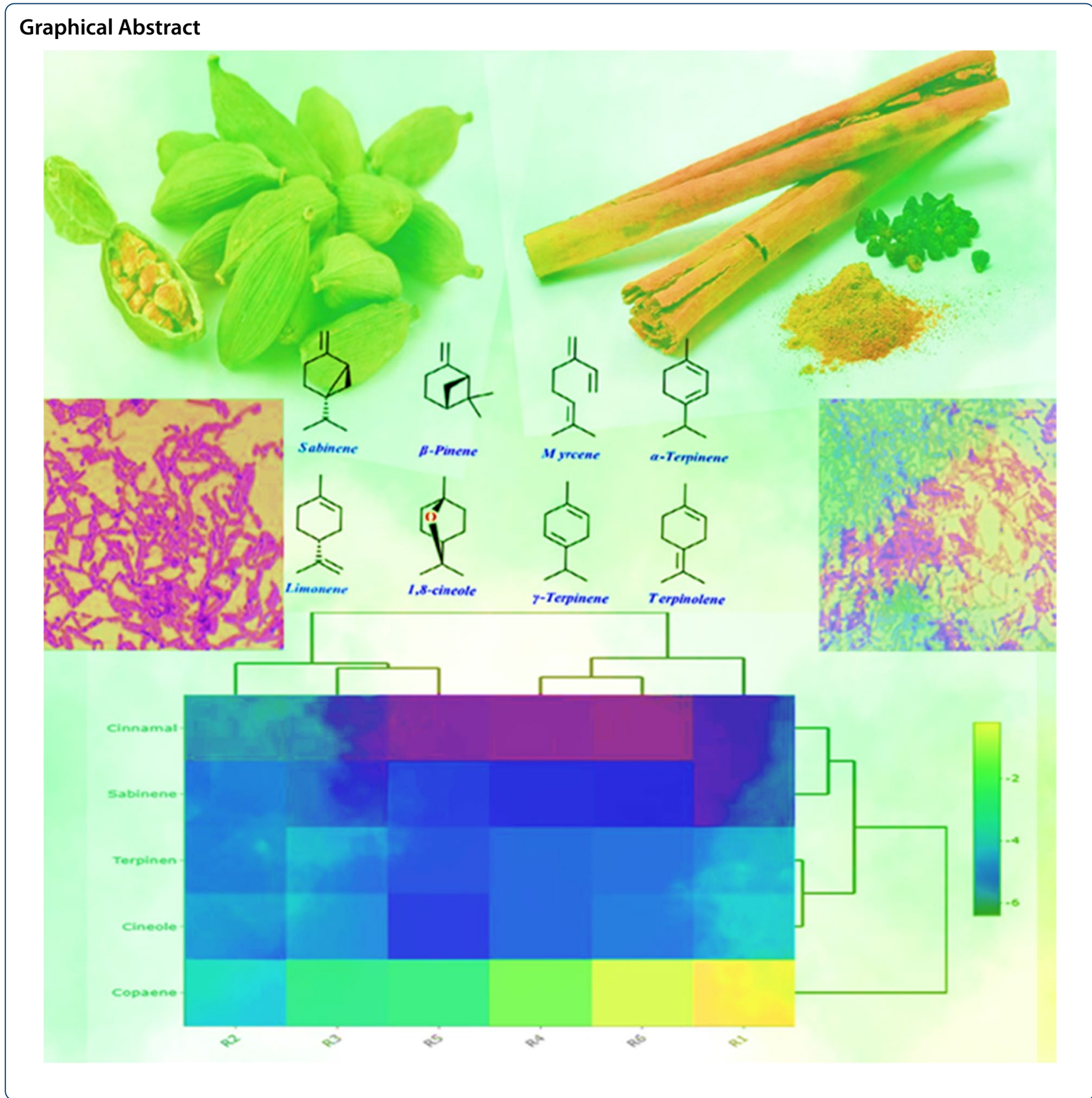

\section{Key points}

- The $\mathrm{Ci} / \mathrm{Ca}$ EOs combination had the lowest antibiofilm activity against $E$. coli compared with pure $\mathrm{Ci}$ and $\mathrm{Ca}$ EOs.

- The $\mathrm{Ci} / \mathrm{Ca}$ EOs combination showed synergistic antibacterial effect against $B$. subtilis.

- The metabolites of two EOs interact with different bacterial targets with moderate to low binding energies.

\section{Introduction}

Today, finding promising natural and synthetic agents with potential anti-bacterial activity is becoming so popular among scientists. A variety of plant extracts (or essential oils) and chemical substances have been evaluated to identify their toxicity profiles on infectious organisms (Zarayneh et al. 2018). Despite all efforts in this field, the accumulating body of evidence suggests that only a few numbers of practical antibacterial agents commercially available to fight against infectious strains (Loolaie et al. 2017). 
Biofilm is a mixture of various groups of microorganisms in a complex with extracellular polymer matrix in which cells bind tightly together on various surfaces (Wang et al. 2020). Biofilm usually creates a sticky gel composed of polysaccharides, proteins and other organic components on a wet surface, that occur in different clinical, industrial and food processing environments and cause serious problems including cross contamination of food products (Muslim et al. 2018). Bacterial biofilms are inherently more tolerant to antibiotic therapies and chemical agents compared with planktonic cells in suspension (Felipe et al. 2019).

According to the review of literature, Escherichia coli, a gram-negative bacterium, is one of the most versatile microorganisms reported in nature, contributes to form biofilm easily on the different surfaces of food industry (Frozi et al. 2017). Similarly, Bacillus subtilis is a grampositive soil bacterium that is constantly exposed to a broad range of environmental stresses (Borriss et al. 2018) and can respond to stressful conditions by forming biofilm on different surfaces (Romero et al. 2010). With resistance to a variety of external stresses, the biofilm formed by $B$. subtilis may cause serious medical problems by making particular wounds difficult to treat, contaminating implants and other medical devices and causing surface corruption in food industries (Ryu and Beuchat 2005).

Over the past decades, EOs reached a great level of academic interest among researchers because of their effectiveness for controlling a variety of infectious organisms. Considerable number of studies have tested EOs biological properties for inhibition of $E$. coli and similar strains. Results indicated that EOs from tea tree, lavender, and lemon balm oil (Budzyńska et al. 2011), cinnamon (Cinnamomum verum L.) showed synergistic effects on biofilm formation of several different bacterial strains. Nevertheless, limited information exists regarding the antibiofilm activity of plant extract or essential oil against B. subtilis (Chemsa et al. 2018). The EOs of $C$. verum $\mathrm{L}$. and cardamom (Elettaria cardamomum L.) display antibacterial activity against both Gram-positive and negative strains. These two plants are among most appreciated medicinal plants in Asian countries, in particular India and Iran, because of their health benefits, antioxidant properties and potential to alleviate gastrointestinal pains (Chemsa et al. 2018; Jamal et al. 2006). However, while practical health benefits of these plants are well understood, there is no report about the antibacterial and antibiofilm activities for the combinatorial effect of the cinnamon/cardamom EOs mixture against $E$. coli and $B$. subtilis and also there is a little bit information regarding molecular mode of action of their biological active compounds.
Recent progresses on computational assays for unraveling the possible interaction of natural products and cellular receptors provided a new way to easily predict the molecular action of plant secondary metabolites. Among applied computational methods, docking analysis is one of the most important and handy methods because of its simple application to predict the inhibitory mode of action of chemical ligands against their favorable receptors (Rasouli et al. 2017, 2020). It is not exaggerating if we say at least half one-third of our knowledge regarding the inhibitory properties of EOs and purified metabolites against a variety of receptors directly generated from docking analyses.

Therefore, the aim of this study was to investigate the antibacterial and antibiofilm activities of cinnamon and cardamom essential oils against E. coli and B. subtilis alone and in combination using in vitro assays. Furthermore, we coupled docking analysis and experimental procedure to show how EOs may inhibit the biofilm formation of infectious bacterial strains that presently causing a variety of problems for both clinics and food industries.

\section{Material and methods \\ Plant material and extraction}

EOs were prepared by hydro-distillation method from the seed of cardamom and the trunk bark of cinnamon using a Clevenger-type apparatus for $3.5 \mathrm{~h}$ (British Pharmacopoeia, 1998). All prepared samples were stored in the dark at $4{ }^{\circ} \mathrm{C}$ for further analysis.

\section{Bacterial strains}

Both Gram-positive B. subtilis (NCTC 5398) and Gramnegative $E$. coli (DH5alpha) bacteria were provided by biotechnology laboratory of Imam Khomeini International University (IKIU).

Determination of minimum inhibitory concentration (MIC) MIC analysis was conducted by using two-fold serial dilution technique as described previously in (Bazargani and Rohloff 2016) in three replicates. The bacterial suspensions were allotted to a concentration approximately $10^{6} \mathrm{CFU} / \mathrm{ml}$ in (Pandey et al. 2011; Sandasi et al. 2010). In all assays to improve the oil solubility, MHB supplemented with $2 \%(\mathrm{v} / \mathrm{v})$ DMSO was used (Silva et al. 2011). Each EO was serially diluted in MHB in a 96-well microtiter plate to have a final $\mathrm{EO}$ concentration ranging from 2.5 to $0.02 \%(\mathrm{v} / \mathrm{v})$. Then $100 \mu \mathrm{l}$ of bacterial suspension was inoculated to each well and the plate incubated at $37^{\circ} \mathrm{C}$ for $24 \mathrm{~h}$ (Rangasamy et al. 2007; Sarker et al. 2007). To enhance the accuracy of all assays, positive and negative controls were ciprofloxacin $(1 \mathrm{mg} / \mathrm{ml})$, (used instead of plant extract) and DMSO + MHB (applied instead of 
bacterial solution), respectively (Sandasi et al. 2010). Finally, MTT (3-(4,5-dimethyl-2-thiazolyl)-2,5-diphenyl$2 \mathrm{H}$ tetrazolium bromide) solution $(0.2 \mathrm{mg} / \mathrm{ml})$ was added to each well and the plate, then incubated at room temperature for 10 to $15 \mathrm{~min}$. The lowest concentration of EO with no visible pink-red coloration was recorded as the MIC value.

\section{Determination of fractional inhibitory concentration index (FICl)}

To evaluate the efficacy of possible interaction between EOs against both bacteria strains, serial two-fold dilutions of cinnamon $(2.5-0.02 \% \mathrm{v} / \mathrm{v})$ and cardamom (2.5$0.02 \% \mathrm{v} / \mathrm{v}$ ) EOs were mixed as described in (Fei et al. 2011) and applied on both bacteria with a similar method adopted to assess MIC. Subsequently, $100 \mu \mathrm{l}$ of bacterial suspension was inoculated to each well in a microtiter plate and the plate was incubated at $37{ }^{\circ} \mathrm{C}$ for $24 \mathrm{~h}$. The growth condition was the same as previously used for MIC assay. FIC index (FICI) was calculated using the following formula: $\mathrm{FICI}=\mathrm{FIC}_{\mathrm{A}}$ (MIC of $\mathrm{EOA}$ in combination with $\mathrm{EOB} / \mathrm{MIC}$ of $\mathrm{EOA}$ alone) $+\mathrm{FIC}_{\mathrm{B}}$ ( $\mathrm{MIC}$ of $\mathrm{EOB}$ in combination with $\mathrm{EOA} / \mathrm{MIC}$ of $\mathrm{EOB}$ alone), where EOA and EOB are two different essential oils and FIC $_{A}$ and $\mathrm{FIC}_{\mathrm{B}}$ are fractional inhibitory concentration of EOA and $\mathrm{EOB}$ respectively. To determine the type of interactions, the following thresholds were considered for FICI values: $\mathrm{FICI} \leq 0.5$ for synergistic; $0.5<\mathrm{FICI} \leq 1$ for additivity; $1<\mathrm{FICI} \leq 4$ for indifference or no effect; and $\mathrm{FICI} \geq 4$ for antagonistic effects (Fei et al. 2011; Gutierrez et al. 2009).

\section{Inhibition of initial bacteria cell attachment}

The effect of pure EOs and their combinations on inhibition of initial bacteria cell attachment was determined as a procedure described in (Bazargani and Rohloff 2016). The EOs with an amount similar to their MIC value were added to each well in a 96-well microtiter plate. Ciprofloxacin (MIC value) and MHB were used as positive and negative controls, respectively. Bacteria culture $\left(10^{6} \mathrm{CFU} / \mathrm{ml}\right)$ was inoculated into each well. Also, only MHB was added to blank wells. In order to precede the attachment of cells on the surface, the plate incubated at $37{ }^{\circ} \mathrm{C}$ for $8 \mathrm{~h}$ without any shaking. After incubation and removing the contents of each wells, plates were washed with sterile distilled water for three times and placed at $60{ }^{\circ} \mathrm{C}$ for $45 \mathrm{~min}$. To perform the crystal violet staining assay, the plate was stained with $1 \%$ crystal violet, incubated at room temperature for $15 \mathrm{~min}$, rinsed three times by using sterile distilled water then de-stained with ethanol. Finally, $100 \mu \mathrm{l}$ of the de-stained solution was transferred to a new plate and the absorbance recorded in three replicates at $\mathrm{OD}_{590 \mathrm{~nm}}$ using a microplate ELISA reader (Bio Tek Instruments, USA). The percentage inhibition was calculated with the following formula (Sandasi et al. 2010):

$$
\begin{aligned}
& \text { Percentage inhibition } \\
& \quad=\frac{\mathrm{OD}_{\text {Negative control }}-\mathrm{OD}_{\text {Experimental }}}{\mathrm{OD}_{\text {Negative control }}} \times 100 .
\end{aligned}
$$

\section{Inhibition of biofilm formation and development-biofilm} biomass measurement

The effect of plant EOs and their combinatorial effects to inhibit the biofilm formation and development was determined with a procedure described in Bazargani and Rohloff (2016). After the biofilm formation for $4 \mathrm{~h}$ at $37{ }^{\circ} \mathrm{C}$, plant EO was added to yield a final concentration similar to their respective MIC values and the mixture incubated for $24 \mathrm{~h}$. Crystal violet staining assay was conducted as described in previous section to determine the inhibition of biofilm growth and development.

\section{Biofilm metabolic activity measurement}

The metabolic (respiratory) activity of biofilm was determined by using (XTT) reduction assay as described in Bazargani and Rohloff (2016). After mixing the plant EO with biofilm and incubation for $24 \mathrm{~h}$ at $37^{\circ} \mathrm{C}$, the liquid part from each well was removed and each well washed three times with phosphate-buffered saline (PBS). The sodium salt of XTT (2,3-bis(2-methoxy4-nitro-5-sulfophenyl)-2H-tetrazolium-5-carboxanilide) was dissolved in PBS at a final concentration of $1 \mathrm{mg} /$ $\mathrm{ml}$, filter-sterilized and stored at $80{ }^{\circ} \mathrm{C}$. Menadione was dissolved in acetone to $1 \mathrm{mM}$ and sterilized immediately before each measurement. Then, $100 \mu \mathrm{l}$ PBS was added in each well, and then $13.5 \mu \mathrm{l}$ of fresh XTT/menadione mixture (12.5:1) was mixed in each well. The microtiter

Table 1 MIC values concentration of cardamom and cinnamon essential oils against E. coli and B. subtilis. MIC were evaluated after $24 \mathrm{~h}$ of incubation

\begin{tabular}{llllll}
\hline $\begin{array}{lllll}\text { Concentration } \\
(\% \mathrm{v} / \mathrm{v})\end{array}$ & \multicolumn{2}{l}{ E. coli } & & \multicolumn{2}{l}{ B. subtilis } \\
\cline { 2 - 3 } \cline { 5 - 6 } & Cardamom & Cinnamon & & Cardamom & Cinnamon \\
\hline 2.5 & - & - & - & - \\
1.25 & + & - & + & - \\
0.63 & + & - & + & - \\
0.31 & + & - & + & - \\
0.16 & + & - & + & + \\
0.08 & + & - & + & + \\
0.04 & + & + & + & + \\
0.02 & + & + & + & + \\
\hline
\end{tabular}

+ : Presence of growth; $-:$ absence of growth 
<smiles>C=Cc1ccccc1</smiles>

Styrene<smiles>C=C1CC[C@]2(C(C)C)C[C@H]1C2</smiles>

Sabinene<smiles>C=C(C)[C]1CC=C(C)CC1</smiles>

Limonene<smiles>CC1=CCC(O)(C(C)C)CC1</smiles>

Terpinen-4-ol<smiles>CC1=CCC2(C(C)C)CC1C2</smiles>

a-Thujene<smiles>C=C1CC[C@@H]2C[C@H]1C2(C)C</smiles>

$\beta$-Pinene<smiles>C[C@H]1O[C@]2(C)CC[C@@H]1C2(C)C</smiles>

1,8-cineole<smiles>CC1=CCC2C[C@]3(C)CC[C@H](C(C)C)C2C13</smiles>

Copaene<smiles>CC1=CCC2CC1C2(C)C</smiles>

a-Pinene<smiles>C=CC(=C)CCC=C(C)C</smiles>

Myrcene<smiles>CC1=CCC(C(C)C)=CC1</smiles>

$\gamma$-Terpinene<smiles>CC(=O)c1ccccc1</smiles>

Benzaldehyde<smiles>CC1=CC=C(C(C)C)CC1</smiles>

$\alpha$-Terpinene<smiles>CC1=CCC(=C(C)C)CC1</smiles>

Terpinolene<smiles>CC(=O)OC(C)(C)C1CC=C(C)CC1</smiles>

Fig. $12 \mathrm{D}$ illustration of most frequent chemical compounds isolated from both Eos

plate was gently shaken, covered with aluminum foil and incubated at $37^{\circ} \mathrm{C}$ for 2 to $3 \mathrm{~h}$, then absorbance was read in three replicates at $490 \mathrm{~nm}$ (Pettit et al. 2005). The negative and positive controls and blank wells were prepared as described previously (Chaieb et al. 2011).
Gas chromatography-mass spectrometry (GC/MS)

The chemical components of EOs were determined by GC-MS. EO samples were diluted in hexane $(5 \mu \mathrm{l} / \mathrm{ml}))$, injected in a split mode at a ratio of 1:35 and analysed using an Agilent HP-6890 Gas Chromatograph coupled 
Table 2 FIC, FIC index and the results of interaction of cardamom and cinnamon essential oils combinations against E. coli and B. subtilis

\begin{tabular}{|c|c|c|c|c|c|c|}
\hline \multirow[t]{2}{*}{ Bacteria strain } & \multirow[t]{2}{*}{ Plant EO } & \multicolumn{2}{|c|}{ MIC (\% v/v) } & \multirow[t]{2}{*}{ FIC (\%v/v) } & \multirow[t]{2}{*}{$\mathrm{FICl}$} & \multirow[t]{2}{*}{ Remarks } \\
\hline & & Alone & Combination & & & \\
\hline \multirow[t]{4}{*}{ E. coli } & Cardamom & 2.5 & 0.04 & 0.02 & 0.52 & Additive \\
\hline & Cinnamon & 0.08 & 0.04 & 0.50 & & \\
\hline & Cardamom & 2.5 & 0.04 & 0.02 & 1.02 & Indifferent \\
\hline & Cinnamon & 0.08 & 0.08 & 1 & & \\
\hline \multirow[t]{4}{*}{ B. subtilis } & Cardamom & 2.5 & 0.04 & 0.02 & 0.15 & Synergist \\
\hline & Cinnamon & 0.31 & 0.04 & 0.13 & & \\
\hline & Cardamom & 2.5 & 0.02 & 0.01 & 0.14 & Synergist \\
\hline & Cinnamon & 0.31 & 0.04 & 0.13 & & \\
\hline
\end{tabular}

Table 3 Antibiofilm activity of cardamom and cinnamon essential oils and their combination on inhibition of initial bacteria cell attachment and biofilm formation (growth and development)

\begin{tabular}{|c|c|c|c|c|c|}
\hline \multirow[t]{2}{*}{ Plant EO } & \multirow[t]{2}{*}{ Strain } & \multirow[t]{2}{*}{$\begin{array}{l}\text { MIC value (\%v/v) } \\
\text { Concentration }\end{array}$} & \multirow{2}{*}{$\begin{array}{l}\text { \% Inhibition of bacteria } \\
\text { attachment } \\
\text { Crystal violet }\end{array}$} & \multicolumn{2}{|c|}{$\begin{array}{l}\% \text { Inhibition of biofilm } \\
\text { formation }\end{array}$} \\
\hline & & & & Crystal violet & XTT \\
\hline Cardamom & E. coli & 2.5 & 92 & 68 & 57 \\
\hline Cinnamon & & 0.08 & 100 & 100 & 99 \\
\hline Cardamom/Cinnamon & & $0.04 / 0.04$ & 62 & 58 & 61 \\
\hline Cardamom & B. subtilis & 2.5 & 76 & 41 & 33 \\
\hline Cinnamon & & 0.63 & 54 & 55 & 36 \\
\hline Cardamom/Cinnamon & & $0.02 / 0.04$ & 80 & 98 & 58 \\
\hline
\end{tabular}

with Agilent HP-5973 mass selective detector equipped with a BPX5 fused silica column $(30 \mathrm{~m} \times 0.25 \mathrm{~mm}$ ID, $0.25 \mu \mathrm{m}$ film thickness). The GC column temperature was programmed from 50 to $300{ }^{\circ} \mathrm{C}$ via a ramp of $3{ }^{\circ} \mathrm{C} /$ min, and maintained at $300{ }^{\circ} \mathrm{C}$ for additional $3 \mathrm{~min}$. The carrier gas was helium with a flow rate of $0.5 \mathrm{ml} / \mathrm{min}$. The MS source was adjusted to $220^{\circ} \mathrm{C}$, and a mass range of $\mathrm{m} / \mathrm{z}$ 40-500 was recorded acquiring all mass spectra in EI mode. The chromatogram visualization and determining the peak area integration was performed with Agilent Chemstation software (Agilent Technologies, Waldbronn, Germany). EOs chemical constituents were identified based on search in MS database using Mass Spectral Library (NIST 05), an in-house retention index library of MS spectra of volatile organic compounds, and comparison of spectra with MS data reported in literature (Sparkman 2005).

\section{Microscopic visualization of biofilm}

The effect of plant EOs on inhibition of biofilm formation was visualized with microscopic as described in Bazargani and Rohloff (2016). The biofilm formation (as described above) was performed on round cover glass slides (diameter $1 \mathrm{~cm}$ ) placed in 24-well plate (Greiner Bio-One, France). The pure and combinatorial EOs with an amount similar to MIC value with high and low antibiofilm activity against bacteria were added to the developed biofilm. The negative and positive controls were also prepared as described above and the plate incubated for $24 \mathrm{~h}$ at $37^{\circ} \mathrm{C}$. The glass slides were stained with $1 / 20$ (v/v) Giemsa (Sigma, Switzerland) solution for $20 \mathrm{~min}$ at room temperature. For different treatments, biofilm formation was visualized using a light microscope with $100 \times$ magnification (Bazargani and Rohloff 2016; Chaieb et al. 2011).

\section{Computational details}

To show the binding mode of action of active compounds isolated from both plants using GC/MS procedure, docking analysis were performed. First, the "sdf" format of identified ligands were created using Gaussian 03 software and then converted into ".pdb" formats. All prepared ligands were optimized using the above-mentioned software for docking analysis. According to GC/ MS output, most of identified compounds in these plants were terpenes and their chemical backbone were selected 
as input chemical ligands for generating docking poses. To perform docking analysis, we used AutoDock Tools and vina scripts. Receptors were chosen among proteins that critically are important for biofilm formation. In this regard, X-ray crystallographic structure of proteins including Bap1 (pdb id: IND1), FabH (pdb id: 1HN9), FtsZ (pdb id: 2VXY), MerB (pdb id: 2WUS), RbmC (pdb id: 5V6C) and RbmA (pdb id: 4KKP) were obtained from PDB database. The receptors were checked for unfavorable atoms, and all water molecules were deleted within the downloaded $p d b$ files. After that, polar hydrogens and surface charges were added to these receptors and their main backbone were selected for docking analysis. UCSF chimera was used for visualizing the docked poses and all docking steps were checked for possible errors and producing false-positive results.

\section{Results}

Determination of minimum inhibitory concentration (MIC) Antimicrobial activities of EOs of E. cardamomum L. and C. verum $\mathrm{L}$. displayed the highest antibacterial activity with MIC values of $0.08 \%$ and $0.31 \%(\mathrm{v} / \mathrm{v})$ against $E$. coli and B. subtilis, respectively (Table 1 ). Figure 1 also represents 2D graphical illustration of frequent chemical constituents isolated from studied EOs.

\section{The combinatorial assay}

The FIC values for the combinatorial antibacterial effect ranged from $0.03 \%$ to $2 \%$ and $0.01 \%$ to $0.13 \%$ against $E$. coli and B. subtilis, respectively (Table 2). A synergistic effect (FIC index $<0.5$ ) was observed only against $B$. subtilis for two combinations, $1 / 64$ MIC of cardamom $+1 / 8$ MIC of cinnamon and 1/128 MIC of cardamom $+1 / 8$ MIC of cinnamon with a FIC index of 0.15 and 0.14 , respectively. However, the FIC index for combinatorial effect with 1/64 MIC of cardamom +1 MIC of cinnamon and 1/64 MIC of cardamom $+1 / 2 \mathrm{MIC}$ of cinnamon with no inhibition effect on $E$. coli growth was 1.02 (indifferent) and 0.52 (additive), respectively (Table 2 ).

\section{Inhibition of initial bacteria cell attachment (biofilm inhibition)}

The results of anti-adhesion tests conducted with the crystal violet assay showed that $\mathrm{CiEO}$ inhibited cell attachment of $E$. coli completely (100\% inhibition activity), while $\mathrm{CaEO}$ and their combination (1/64 MIC of cardamom $+1 / 2$ MIC of cinnamon) displayed $92 \%$ and $62 \%$ inhibition against $E$. coli, respectively (Table 3 ). Moderate inhibition was observed for EOs against B. subtilis and their combination against E. coli (Table 3). B. subtilis was more resistant than $E$. coli with a lower inhibition, $54 \%$ and $76 \%$ for $\mathrm{Ci} / \mathrm{Ca}$ EOs, respectively. However, the combination $1 / 128 \mathrm{MIC}$ of cardamom $+1 / 8 \mathrm{MIC}$ of cinnamon showed more inhibition, $80 \%$ compared with pure EOs against B. subtilis (Table 3).

In general, the amount of inhibition of biofilm formation was less pronounced compared to inhibition of initial attachment except for $\mathrm{CiEO}$ which showed the same inhibitory activity at attachment and biofilm formation against both bacteria. Also, $\mathrm{Ci} / \mathrm{Ca}$ EOs combination showed $98 \%$ inhibitory biofilm formation activity at MIC value of $0.02 / 0.04 \%(\mathrm{v} / \mathrm{v})$ against $B$. subtilis which was more observed compared with inhibition of initial attachment (Table 3).

The reduced inhibition of biofilm development demonstrated that the bacteria cells in a biofilm are more resistant to antimicrobial agents compared to planktonic cells. In fact, inhibition of biofilm growth and development is more difficult to achieve than inhibition of cell attachment. These results are consistent with the results of previous studies (Bazargani and Rohloff 2016; Sandasi et al. 2008). Based on the findings of the present study, $\mathrm{CiEO}$ and $\mathrm{Ci} / \mathrm{Ca}$ EOs mixture exhibited the highest inhibitory biofilm formation activity against $E$. coli and $B$. subtilis respectively with lowest MIC values $(0.08 \%$ and $0.02 / 0.04 \% \mathrm{v} / \mathrm{v})$ (Table 3$)$. It has been reported that oregano oil at $0.1 \%(\mathrm{v} / \mathrm{v})$ inhibited biofilm formation of $E$. coli (Oral et al. 2010). The Cinnamomum zeylanicum EO inhibited biofilm formation at inhibitory concentration of $1.92 \%(\mathrm{v} / \mathrm{v})$ which was the most satisfactorily with $E$. coli reduction of biomass (Millezi et al. 2019). The essential oil of another cinnamon species (Cinnamomum burmannii) was able to inhibit biofilm formation of $S$. aureus and P. aeruginosa by $50 \%$ at concentration of $0.03 \%(\mathrm{v} / \mathrm{v})$ and destabilized biofilms of both bacteria at a concentration of $0.12 \%$ (v/v) (Pratiwi et al. 2015). Other studies have reported effectively removal of $E$. coli and S. epidermidis biofilms by CiEO (de Oliveira et al. 2012; Nuryastuti et al. 2009). Interestingly, Oh et al (2017) evaluated the effects of single and blended essential oils of thymol, oregano and cavacrol on biofilm formation of Salmonella and E. coli. They observed single essential oil had a better antibiofilm property than blended essential oil (Oh et al. 2017). In that study, thymol and oregano EOs had a better antibiofilm activity against $E$. coli than cavacrol EO and in comparison to oregano EO, both cavacrol and thymol EOs had a better antibiofilm effect on Salmonella (Oh et al. 2017). Similar to previous investigations, the current study showed CiEO had a more antibiofilm activity against $E$. coli bacterial biofilm than cardamom and $\mathrm{Ci} / \mathrm{Ca}$ EOs mixture. Nevertheless, Ci/ Ca EOs combination indicated more percentage inhibition of B. subtilis biofilm formation than single essential oil which may be related to synergistic antibacterial effect of blended EOs against this bacterium. 
Table 4 Chemical composition (\%) of cinnamon and cardamom essential oils

\begin{tabular}{|c|c|c|c|c|}
\hline Compound & $\mathrm{RI}^{\mathrm{a}}$ & Cinnamon & Cardamom & $\begin{array}{l}\text { Type of } \\
\text { compound }\end{array}$ \\
\hline Styrene & 907 & 1.08 & $-{ }^{\mathrm{b}}$ & Other \\
\hline$a$-Thujene & 938 & - & 0.13 & $\mathrm{MH}$ \\
\hline a-Pinene & 946 & - & 1.06 & $\mathrm{MH}$ \\
\hline Benzaldehyde & 986 & 0.43 & - & Other \\
\hline Sabinene & 988 & - & 3.06 & $\mathrm{MH}$ \\
\hline$\beta$-Pinene & 993 & - & 0.48 & $\mathrm{MH}$ \\
\hline Myrcene & 1004 & - & 1.13 & $\mathrm{MH}$ \\
\hline$a$-Terpinene & 1033 & - & 0.29 & $\mathrm{MH}$ \\
\hline Limonene & 1044 & 0.13 & - & $\mathrm{MH}$ \\
\hline 1,8-cineole & 1050 & 1.22 & 49.10 & $\mathrm{MO}$ \\
\hline$\gamma$-Terpinene & 1075 & - & 0.55 & $\mathrm{MH}$ \\
\hline cis-Sabinene hydrate & 1089 & - & 0.38 & $\mathrm{MO}$ \\
\hline Terpinolene & 1101 & - & 0.20 & $\mathrm{MH}$ \\
\hline Linalool & 1118 & - & 0.47 & $\mathrm{MO}$ \\
\hline trans-Sabinene hydrate & 1121 & - & 0.31 & $\mathrm{MO}$ \\
\hline Terpinen-4-ol & 1203 & - & 2.15 & $\mathrm{MO}$ \\
\hline$a$-Terpineol & 1219 & 0.09 & 1.57 & $\mathrm{MO}$ \\
\hline Linalyl acetate & 1265 & - & 0.33 & $\mathrm{MO}$ \\
\hline Geraniol & 1271 & - & 0.92 & $\mathrm{MO}$ \\
\hline Cinnamaldehyde & 1278 & 0.48 & 0.42 & Other \\
\hline E-Cinnamaldehyde & 1321 & 84.23 & - & Other \\
\hline Methyl geranate & 1342 & - & 0.15 & $\mathrm{MO}$ \\
\hline$a$-Terpinyl acetate & 1370 & 3.51 & 35.54 & $\mathrm{MO}$ \\
\hline Copaene & 1395 & 3.57 & - & $\mathrm{SH}$ \\
\hline Caryophyllene & 1441 & 0.25 & - & $\mathrm{SH}$ \\
\hline $\begin{array}{l}\text { Acetic acid, cinnamyl } \\
\text { ester }\end{array}$ & 1477 & 0.26 & - & Other \\
\hline a-Amorphene & 1497 & 0.24 & - & $\mathrm{SH}$ \\
\hline$\beta$-Selinene & 1513 & - & 0.28 & $\mathrm{SH}$ \\
\hline$a$-Selinene & 1514 & 0.11 & - & $\mathrm{SH}$ \\
\hline a-Muurolene & 1522 & 0.83 & - & $\mathrm{SH}$ \\
\hline$\delta$-Cadinene & 1541 & 0.90 & - & $\mathrm{SH}$ \\
\hline Cadine-1,4-diene & 1547 & 0.39 & - & $\mathrm{SH}$ \\
\hline Nerolidol & 1581 & - & 0.26 & so \\
\hline$a$-Cadinol & 1675 & 0.27 & - & $\mathrm{MO}$ \\
\hline Total identified (\%) & & 97.99 & 98.77 & \\
\hline $\begin{array}{l}\text { Monoterpenes (MT), } \\
\text { total }\end{array}$ & & 5.22 & 97.82 & \\
\hline oxygenated MT & & 5.09 & 90.92 & \\
\hline $\begin{array}{l}\text { Sesquiterpenes (ST), } \\
\text { total }\end{array}$ & & 6.29 & 0.54 & \\
\hline oxygenated ST & & - & 0.26 & \\
\hline
\end{tabular}

$\mathrm{MH}$ monoterpene hydrocarbons, $\mathrm{MO}$ oxygenated monoterpenes, $\mathrm{SH}$ sesquiterpene hydrocarbons, SO oxygenated sesquiterpenes

${ }^{\mathrm{a}}$ Kovats retention index. ${ }^{\mathrm{b}}$ Below threshold level of $<0.01$, or not detected, Levels of major compounds ( $\geq 2 \%$ ) are marked in bold
Inhibition of biofilm formation-biomass quantification (crystal violet assay)

The results of quantification of biofilm biomass revealed that EO of cinnamon inhibited biofilm formation of E. coli completely (100\% inhibition activity) while EO of cardamom and the combination 1/64 MIC of cardamom $+1 / 2$ MIC of cinnamon induced inhibition of biofilm formation against E. coli up to $68 \%$ and $58 \%$, respectively (Table 3). In comparison, EO of cinnamon displayed a low biofilm inhibition (55\%) against B. subtilis. Similarly, EO of cardamom exhibited $41 \%$ inhibition activity against biofilm formed by $B$. subtilis whereas their combination, $1 / 128$ MIC of cardamom $+1 / 8$ MIC of cinnamon showed a high inhibition (98\%) and thus a strong antibiofilm activity compared with pure EOs against B. subtilis (Table 3). Moreover, B. subtilis showed more resistance to pure EO than E. coli.

\section{Inhibition of biofilm formation-metabolic activity (XTT assay)}

The results of evaluation metabolic (respiratory) activity of biofilm indicated that pure EOs and their mixture decreased metabolic activity of bacterial cells in biofilms formed by E. coli and B. subtilis, with 57 to $99 \%$ and 33 to $58 \%$ inhibition, respectively (Table 3 ). CiEO was most effective to inhibit the biofilm formation of $E$. coli by $100 \%$ indicating decomposing and degrading the biofilm completely. Our data also provided evidence that CiEO had the highest inhibitory potential in which could reduce metabolic activity of $E$. coli by $99 \%$. The EOs mixture didn't have any more reduction compared to pure EOs. Ci/Ca EOs displayed a lower reduction (36\% and $33 \%$, respectively) in metabolic activity against $B$. subtilis biofilm compared to E. coli. The EOs mixture (1/128 MIC of cardamom $+1 / 8$ MIC of cinnamon) showed more reduction $(58 \%)$ in metabolic activity against $B$. subtilis (Table 3). B. subtilis had a more resistance to reduction in metabolic activity by using pure EO than E. coli (Table 3 ). Moreover, the results of anti-adhesion, crystal violet and $\mathrm{XTT}$ assays revealed that the pure $\mathrm{CiEO}$ (at MIC value of $0.08 \%$ ) and in combination with $\mathrm{CaEO}$ (with MIC value of 0.02 and $0.04 \%$ respectively) were effective in reduction of biofilm biomass and also in reducing metabolic activity of biofilm formed by E. coli and B. subtilis.

As shown in Table 3, the biomass production and metabolic activity assay were almost identical. Moreover, the inhibition of biofilm formation by both EOs was also confirmed by XTT reduction assay. With the exception of $\mathrm{CiEO}$ combination with $\mathrm{CaEO}$ used against $B$. subtilis, which the result of XTT reduction assay was not correlated with crystal violet assay inhibition of biofilm formation (Table 3). Despite of the increased inhibitory effect of biofilm formation, the metabolic activity did not 
decrease significantly compared to the inhibited biofilm. In this regard, several studies indicated an inverse correlation or no correlation between biomass production and metabolic activity for plant extract or essential oil (Budzyńska et al. 2011; Kwieciński et al. 2009; Sandasi et al. 2008). Overall, the essential oil of cinnamon had the highest inhibitory effect on the biofilm growth against both tested bacteria particularly $E$. coli and the combination of $\mathrm{Ci} / \mathrm{Ca}$ EOs had the best effect against B. subtilis biofilm.

\section{Chemical composition of essential oils}

In total, 17 and 21 chemical compounds were identified with GC-MS analyses in cinnamon and cardamom, respectively (Table 4). Three main components including E-cinnamaldehyde, copaene and $\alpha$-terpinyl acetate constituted $91.31 \%$ of the CiEO. In contrast, 1,8-cineole, $\alpha$-terpinyl acetate, sabinene, and $\alpha$-terpinen-4-ol were the main constituents (89.58\%) of CaEO (Table 4). The total amount of terpenes in essential oil of cinnamon and cardamom was $11.51 \%$ and $98.36 \%$ respectively, of which $5.09 \%$ and $90.92 \%$ were oxygenated monoterpenes.

\section{Microscopic visualization of biofilm formation}

The high inhibition of biofilm formation by pure Ci EO and $\mathrm{Ci} / \mathrm{Ca}$ EOs combination against E. coli and B. subtilis was also observed using microscopic visualization respectively (Fig. 2). The induction of biofilm growth and development was evident by $\mathrm{CaEO}$ and mixture of both EOs (with poor antibiofilm activity) against $B$. subtilis and $E$. coli respectively. The inhibition pattern of biofilm formation for ciprofloxacin (positive control) was similar to that observed for CiEO.

\section{Molecular docking outputs}

Docking analysis is an excellent toolkit to support researchers for unravelling the exact molecular action of protein-ligands. In some cases, that access to experimental data is not provided, using docking strategy can pave a way to interpretate molecular aspects of cells. In this study, we used this method to determine how active constituents of $\mathrm{CiEO}$ and $\mathrm{CaEO}$ could biologically interact with molecular targets within bacterial biofilms. Six receptors (Fig. 3) were selected and binding mode inhibitory profile of these compounds were investigated.

As shown in Fig. 4, docked compounds exactly inserted within active site cavity. Although these compounds displayed a similar binding energy, nevertheless, $E$-cinnamaldehyde showed higher tendency to bind to catalytic residues in this active site. The binding docking energy for this compound was $-5.9 \mathrm{kcal} \mathrm{mol}^{-1}$. This compound was the only constituent that could form $\mathrm{H}$-bonds with the active site of $\beta$-Ketoacyl-Acyl Carrier Protein Synthase III. Qiu et al. (2001) reported that several different amino acids including Cys112, Leu142, Phe157, Leu189, Asn274, Gly305 and Gly306 are critical residues in this cavity that modulate the functionality of enzyme in the presence of its substrate. Our docking results displayed that His244 and Phe304 were two residues that could build $\mathrm{H}$-bond with the side chain of $E$-cinnamaldehyde metabolites. Among docked compounds for this receptor, copaene showed the lowest docking binding energy in which $-0.2 \mathrm{kcal} \mathrm{mol}^{-1}$ was its interaction energy. While sabinene possessed docking energy equals to $-5.9 \mathrm{kcal}$ $\mathrm{mol}^{-1}$, this compound doesn't build H-bond with possible catalytic residues in this active cite. 1,8-cieole and terpinene-4-ol compounds also inserted in this cavity and their docking energies were -4.1 and $-4.3 \mathrm{kcal} \mathrm{mol}^{-1}$, respectively.

FtsZ protein was another receptor that used for docking analysis. Haydon et al. (2008) reported that residues including Ile172, Val173, Phe183, Gln192, Arg191, Ile228, Leu302 and Val307 are critical amino acids in FtsZ active site. According to their results, potential inhibitors can bind to this active site to disrupt the normal functionality of this protein. Our results showed that E-cinnamaldehyde possessed the best docking energy $\left(-6.1 \mathrm{kcal} \mathrm{mol}^{-1}\right)$ for this active site and formed an observable H-bond. Sabinene was another metabolite that lodged inside this active site and possessed docking energy equals to $-5.0 \mathrm{kcal} \mathrm{mol}^{-1}$. Other compounds also interacted with FtsZ active site by gaining docking energies ranged from -3.5 to $-5.0 \mathrm{kcal} \mathrm{mol}^{-1}$, respectively. Figure 5 represents graphical illustration of four docked compounds into FtsZ active site.

For other receptors, the studied metabolites showed similar binding energies and $E$-cinnamaldehyde has built $\mathrm{H}$-bond with all active sites (Additional file 1). These types of interactions suggested that individual substances of EOs may select different targets for showing their biological properties. Although further high-quality computational and experimental assays should be performed on these compounds to reveal their mode of action, the current results partially prove their potency to disrupt the

(See figure on next page.)

Fig. 2 Light microscopy assay. Effect of essential oils (EO) on inhibition of biofilm formation (growth and development); Escherichia coli, $\mathbf{A} 1$ bacteria supplemented with EO of cinnamon at MIC (high activity), B1 bacteria supplemented with Ci/Ca EOs combination MIC (poor activity), C1 positive control (bacteria supplemented with antibiotic MIC), D1 negative control (non-treated slides). Bacillus subtilis, A2 bacteria supplemented with EO of cinnamon/cardamom combination at MIC (high activity), B2 bacteria supplemented with CaEO at MIC (poor activity), $\mathbf{C 2}$ positive control (bacteria supplemented with antibiotic MIC), D2 negative control (non-treated slides) 

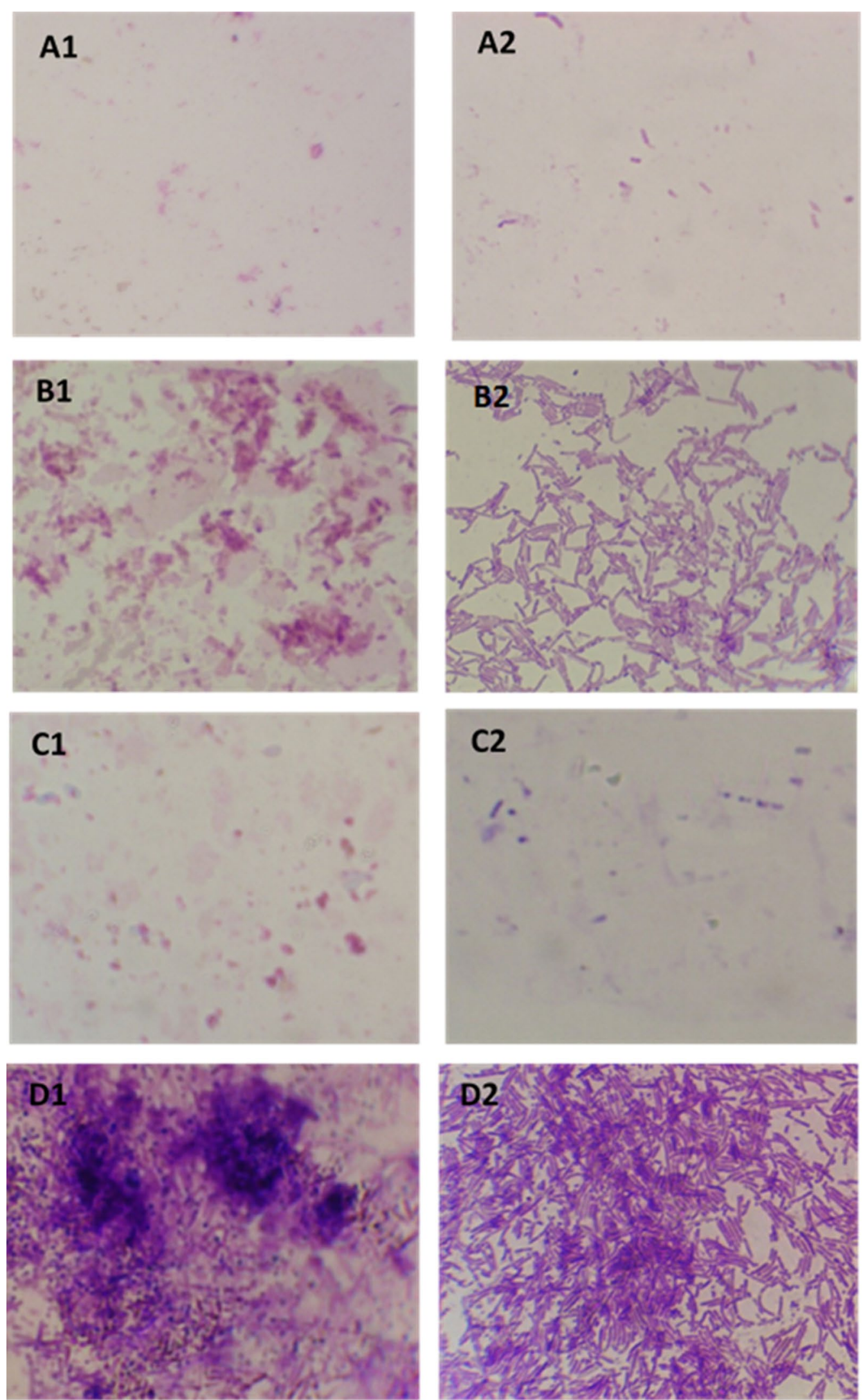

Fig. 2 (See legend on previous page.) 


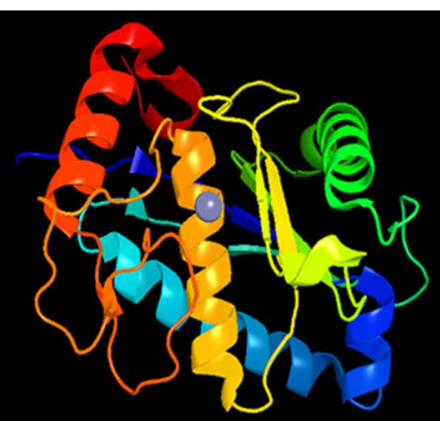

PDB id: INDI

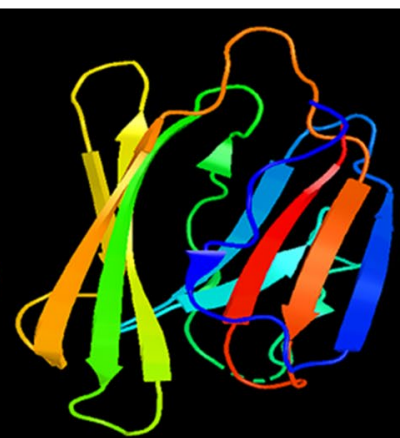

PDB id: 5V6C

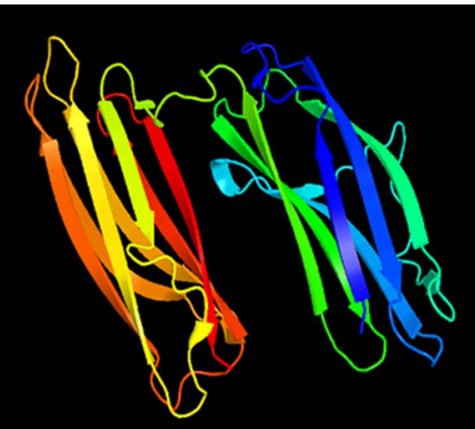

$P D B$ id: $4 K K P$

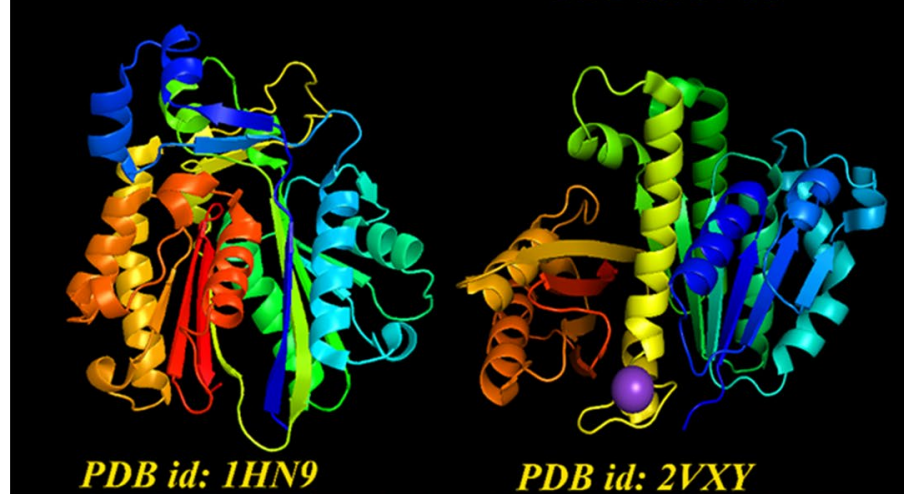

$P D B$ id: $2 V X Y$

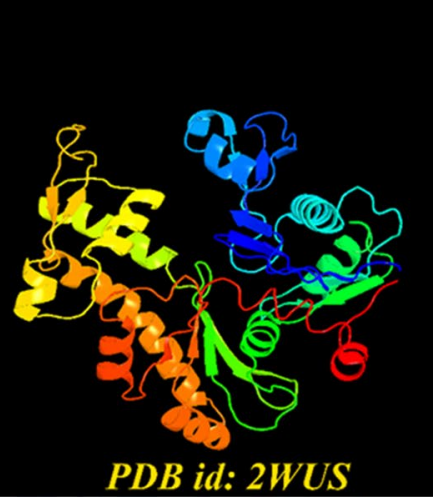

Fig. 3 The graphical illustration of selected receptors for docking studies

formation of biofilm among studied infectious strains. According to Fig. 6, Copaene showed lowest binding energies for receptor 1, 4 and 6, respectively. At all, this compound was not able to form strong chemical bonds within the target active sites because of its unique chemical backbone. In contrast, $E$-cinnamaldehyde unravelled higher interaction tendency to approach the catalytic residues of target active sites. For other metabolites, similar binding energies for conducted docking analyses were observed.

Based upon docking binding energies, the tendency of target receptors to interact with the docked compounds was investigated, and the results unraveled that receptors 4,5 and 6 were the most favorable receptors to absorb the scaffold of ligands into their active site. Therefore, the conformational structure of active sites is a critical parameter that may change the interaction power between ligands and receptors. According to Rasouli et al. study (2020), to determine the type of interaction between ligands and active site residues, the most important factor is the variability of ligands backbones that could strongly affect the affinity of ligands to lodge into active site cavity. In their study, the authors determined that the differences between binding energies for docked compounds were due to structural changes of functional groups attached to the main scaffold of investigated plant metabolites. Here, our results also were in line with that study and the conformational size of docked active sites and chemical backbone of docked ligands determined the calculated binding energies. The following figure also illustrates the correlation of calculated binding energies for each receptor during molecular docking simulation (Fig. 7).

\section{Discussion}

Today, finding an excellent and practical strategy to deter the possible growth of bacterial strains through inhibition of biofilm formation using various methods received a considerable attention from both academia and food industries. Among the applied methods for inhibition of biofilm formation, using natural products may provide lots of benefits for target industries because of availability of natural sources and their cheap cost. The most favorable technique that has presently been utilized is to apply EOs for this purpose. It seems quite clear that EOs are including considerable volume of purified secondary metabolites that can enter bacterial communities or cells to interact with a variety of molecular targets, leading to gradual inhibition of bacterial growth (Kerekes et al. 2019; Zhang et al. 2018).

As we shown in experimental assays, CiEO exhibited stronger antibacterial effect against both E. coli and 


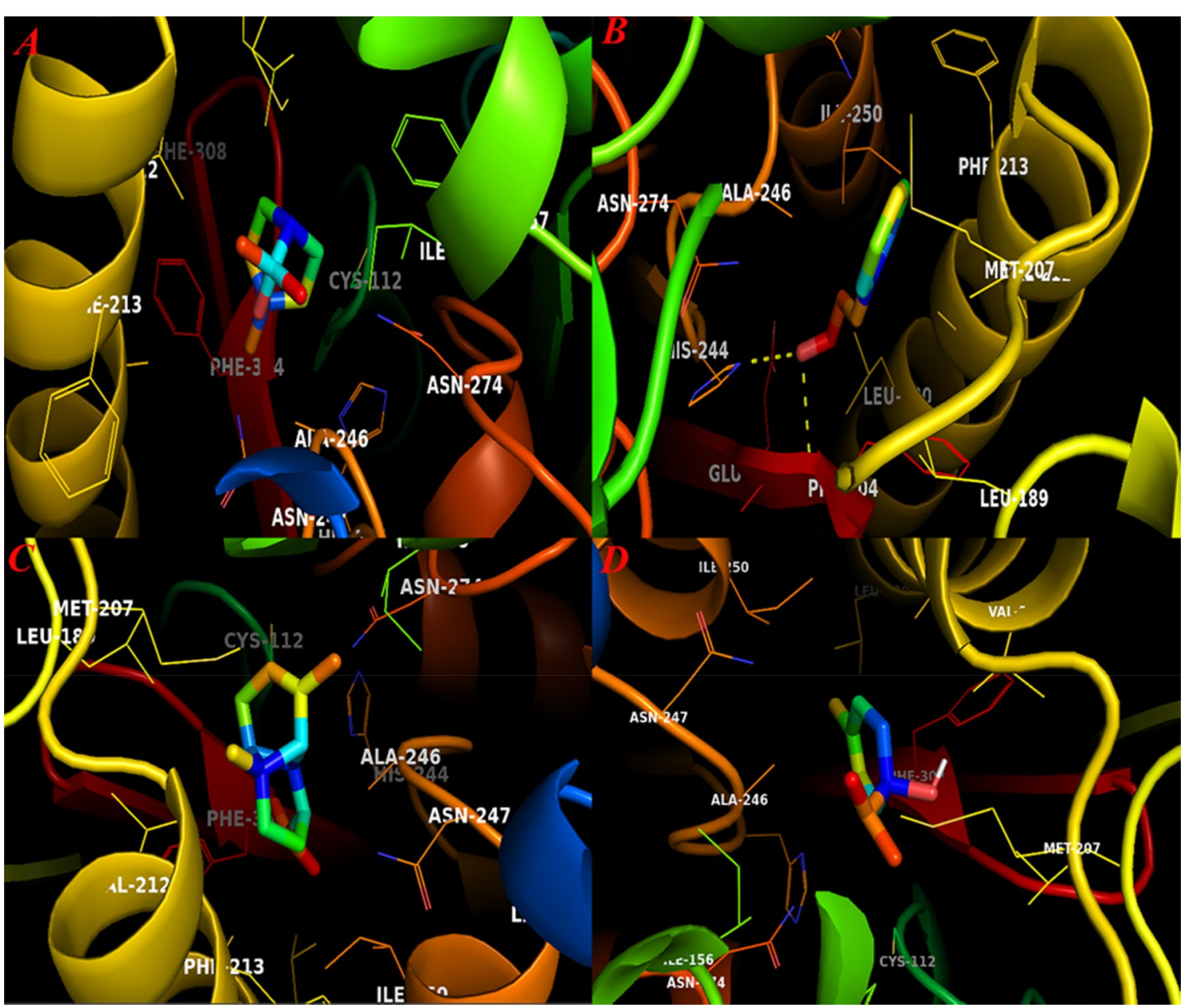

Fig. 4 The graphical illustration of docked ligands and $\beta$-Ketoacyl-Acyl Carrier Protein Synthase III. A 1,8-cineole; B E-Cinnamaldehyde; C Copaene and $\mathbf{D}$ Terpinen-4-ol

B. subtilis (with lower MIC value of 0.08 and $0.31 \% \mathrm{v} / \mathrm{v}$, respectively) compared with $\mathrm{CaEO}$ with $\mathrm{MIC}$ value of $2.5(\% \mathrm{v} / \mathrm{v})$ against both bacteria. Interestingly, the growing body of evidence suggests that the C. cassia EO and its major constituent, i.e., cinnamaldehyde unravel active antimicrobials potential with a broad-spectrum activity (Chang et al. 2001; de Oliveira et al. 2012; Gill and Holley 2004; Ooi et al. 2006; Oussalah et al. 2007). Here, antibacterial activity of $\mathrm{CiEO}$ against $E$. coli was higher than B. subtilis. This result was consistent with the results by Fei et al. (2011) that reported CiEO showed higher antibacterial effect against E. coli (MIC value of $0.1 \mu \mathrm{l} / \mathrm{ml}$ ) than B. subtilis (MIC value of $0.2 \mu \mathrm{l} / \mathrm{ml}$ ) (Fei et al. 2011). Whereas CaEO had lower antibacterial effect against both of Gram-negative and Gram-positive bacteria with MIC value of $2.5(\% \mathrm{v} / \mathrm{v})$ compared to CiEO. Asghar et al (2017) reported MIC values of CaEO in range of 5-10 (\%v/v) against S. typhimurium, S. aureus, S. mutans and C. albicans bacteria strains (Asghar et al. 2017).
The GC/MS results showed, more susceptibility of $E$. coli to antimicrobial activity of $\mathrm{CiEO}$ than $B$. subtilis is because of E-cinnamaldehyde as a main component of CiEO. Trans-cinnamaldehyde (E-cinnamaldehyde) can inhibit the growth of E. coli and S. typhimirium without decomposing the outer membrane or depleting intracellular ATP and can also gain access to the periplasm and deeper portions of the cell (Helander et al. 1997, 1998; Nazzaro et al. 2013).Whereas the CaEO is composed of a considerable volume of monoterpenes. Various studies reported that monoterpenes are biologically active with moderate to high antibacterial profile against both Grampositive and negative bacteria (Trombetta et al. 2005). The mechanisms underlying the antibacterial activity of monoterpenes is depending on variation of their chemical backbone and functional groups attached to their structure (Trombetta et al. 2005). Accordingly, the combination of EOs enriched with monoterpenes with other types of EOs comprised organic constituents may boost 


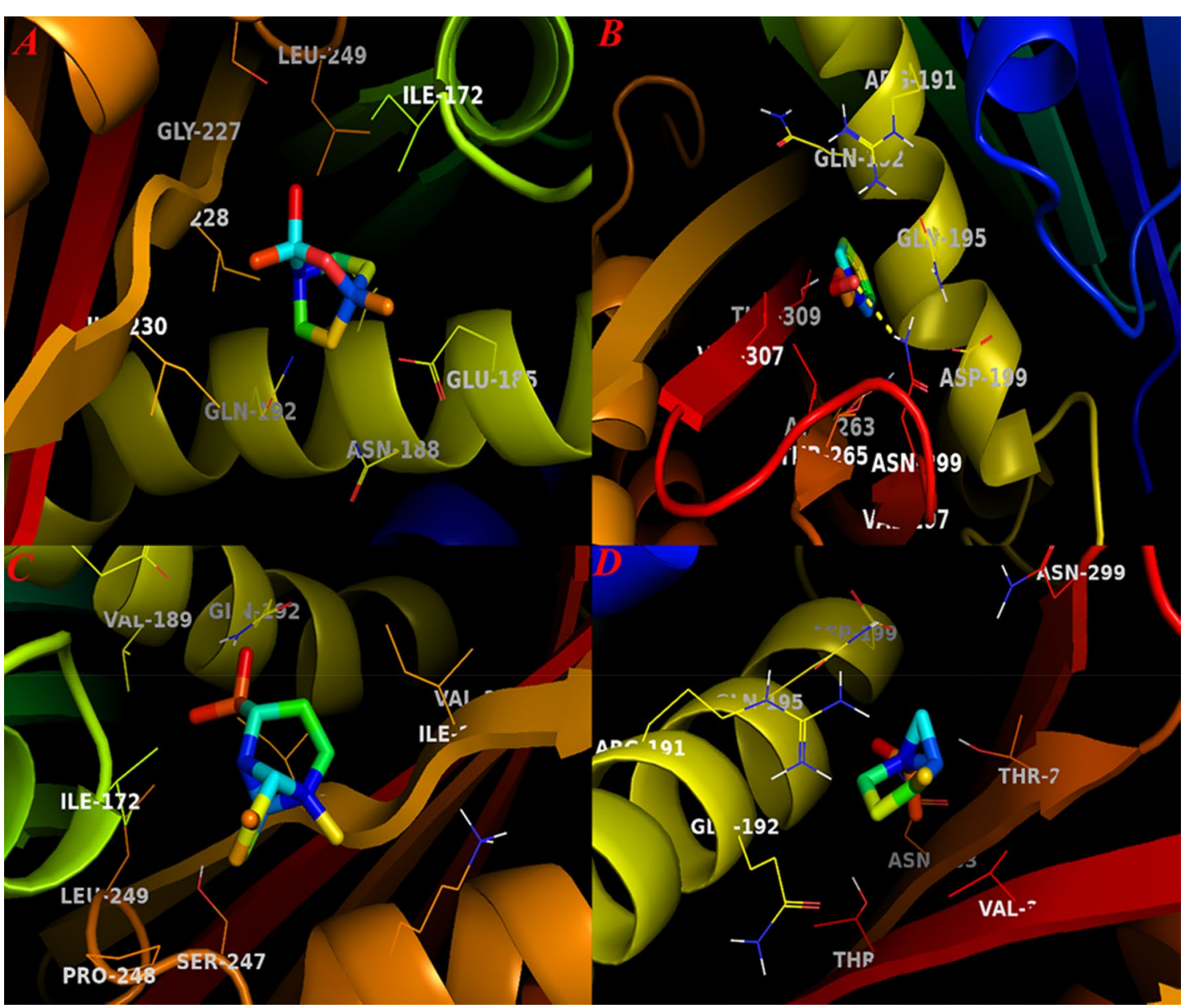

Fig. 5 Graphical illustration docked compounds and FtsZ active site. A 1,8-cineole; B E-cinnamaldehyde; C Copaene and D Sabinene

the strength of antibacterial activity of fused EOs. In this regard, as detailed in Table 2, synergistic and additive antibacterial effects for $\mathrm{Ci} / \mathrm{Ca}$ EOs mixtures against B. subtilis and E. coli isolates were observed. To best of our knowledge, there is no study on the antimicrobial activities of the $\mathrm{Ci} / \mathrm{Ca}$ EOs mixture against $E$. coli and $B$. subtilis: The published studies have focused on the antimicrobial activity of combinations between EO mixtures against E. coli (Fahimi et al. 2015; Semeniuc et al. 2017), thyme/cinnamon EO mixtures against $B$. subtilis and $E$. coli (Semeniuc et al. 2017). Among these combinations, only thyme/oregano (Stojković et al. 2013), thyme/myrtle (Sadiki et al. 2014), thyme/cinnamon (Kon and Rai 2012) and thyme/peppermint EO mixtures (Fahimi et al. 2015) unraveled a synergistic effect. The other combinations have displayed indifferent, additive, and antagonistic effects. In an interesting study, EOs synergistic effect on cell deformation, rupture and lysis of the membrane have been observed for $B$. subtilis cells treated with the combination of oregano oil and bergamot oil at MIC value while an incomplete and deformed shape observed in E. coli cells treated with the combination of oregano oil and basil oil at MIC value (Lv et al. 2011).

Normally, Gram-negative bacteria are more resistant than Gram-positive bacteria because of their characteristic structure of outer membrane serves as an additional barrier making them more resistant to lipophilic molecules and diffusion of the constituents of the EOs into the bacterial cell more difficult (Burt 2004; Mann et al. 2000; Nazzaro et al. 2013). However, in our study biofilm of $B$. subtilis was more resistant to $\mathrm{Ci} / \mathrm{Ca}$ EOs than biofilm of $E$. coli. In this regard, studies reported that the Gram-negative bacteria biofilm (E. coli O157: H7) was more sensitive to antibacterial effect of carvacrol and eugenol compared to the Gram-positive bacteria biofilm (L. monocytogenes) (Perez-Conesa et al. 2006). Similar studies on E. coli and L. monocytogenes bacteria biofilms, the cells of Gram-positive $L$. 


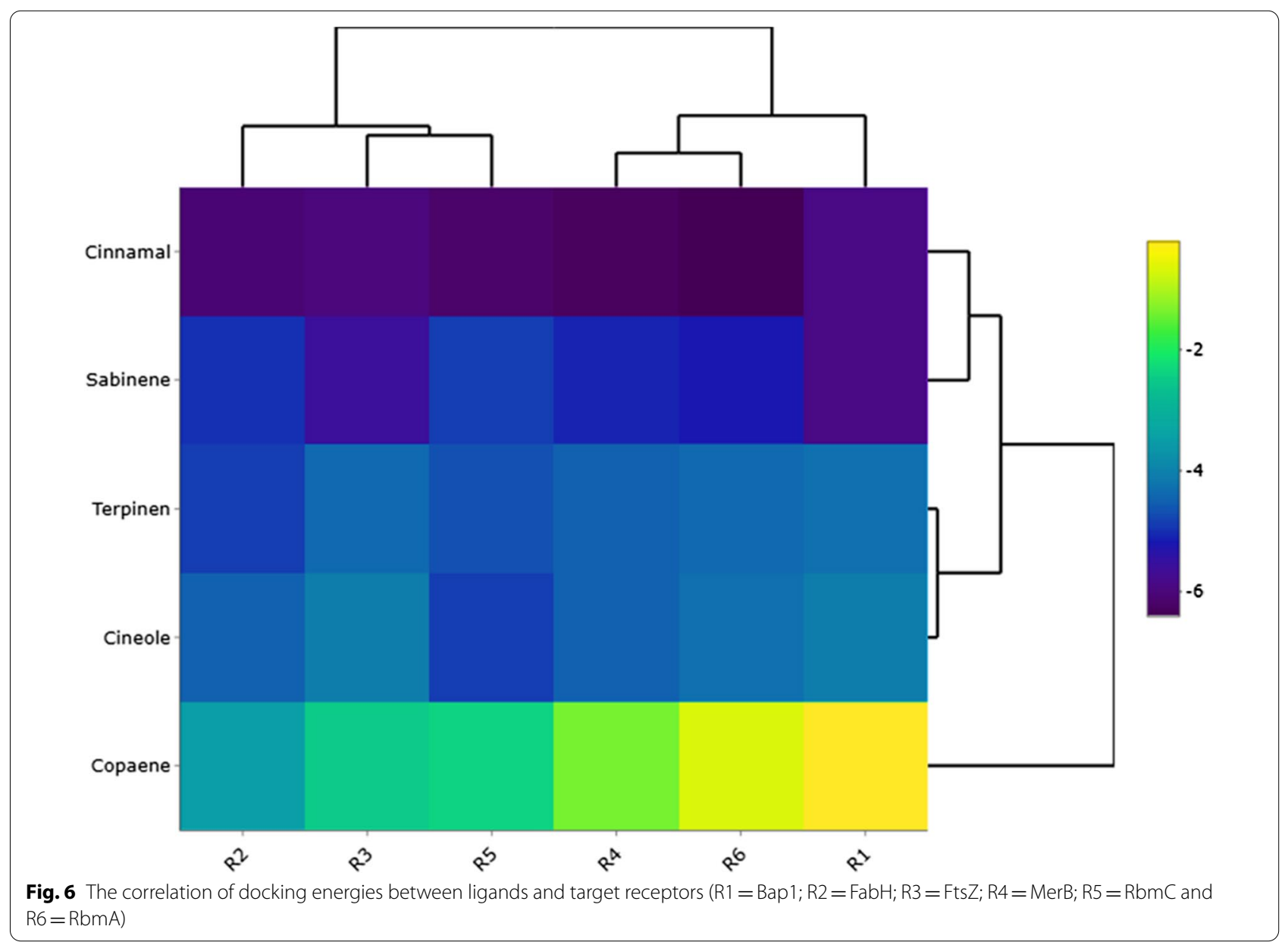

monocytogenes were more resistant to $C$. cassia $\mathrm{EO}$ and cinnamaldehyde than the cells of the Gram-negative $E$. coli (de Oliveira et al. 2012). The antibacterial mechanisms of action of EOs and/or their components are closely related with their chemical compositions which can have a single target or multiple targets of their antibacterial activity. In this regard, EOs could have different mechanisms of action against Gram-positive and Gram-negative bacteria (Nazzaro et al. 2013). In our study, 1,8-cineole (with the highest amount of 49.10\%) and terpinen-4-ol (with low amount of 2.15\%) were the major components of CaEO. According to Kotan (Kotan et al. 2007),lower antibacterial and antibiofilm activities of $\mathrm{CaEO}$ at MIC value of $2.5 \%$ than cinnamon may be related to higher content of 1,8-cineole and lower content of terpinen-4-ol. Singh et al. (2008) observed strong antibacterial activity for $\mathrm{CaEO}$ against $S$. aureus, B. cereus and E. coli at $3000 \mathrm{ppm}$ by the agar well diffusion method. They reported $\alpha$-terpinyl acetate (44.3\%), 1,8-cineole (10.7\%), $\alpha$-terpineol $(9.8 \%)$ and linalool (8.6\%) as major components in which, in comparison to what was observed in our study, $\alpha$-terpineol and linalool (oxygenated monoterpenes with considerable antibacterial activity) were in higher amount and 1,8-cineole (oxygenated monoterpene with no antibacterial activity) was in lower amount (Singh et al. 2008). This confirmed low antimicrobial activity of $\mathrm{CaEO}$ than $\mathrm{CiEO}$ in our study that it may be because of low amounts of $\alpha$-terpineol and linalool in cardamom. Additionally, the higher antibiofilm potential of $\mathrm{CiEO}$ and its combination with $\mathrm{CaEO}$ against $E$. coli and B. subtilis is closely related to their chemical compositions, the action and the presence of certain or principal EO compounds. Terpenes and especially oxygenated monoterpenes consist a major proportion of cardamom EO and are the dominant groups of chemical constituents in the cardamom EO (Table 4). Oxygenated monoterpenes as widespread components of EOs are a class of terpenes that oxygenated (Chrysargyris et al. 2020). On screening of antibacterial activities of 21 oxygenated monoterpenes, linalool, nerol, $\alpha$ terpineol, fenchol, terpinen-4-ol showed antibacterial activity against a wide range of bacteria. In contrast to these compounds, no inhibitory activity was observed 


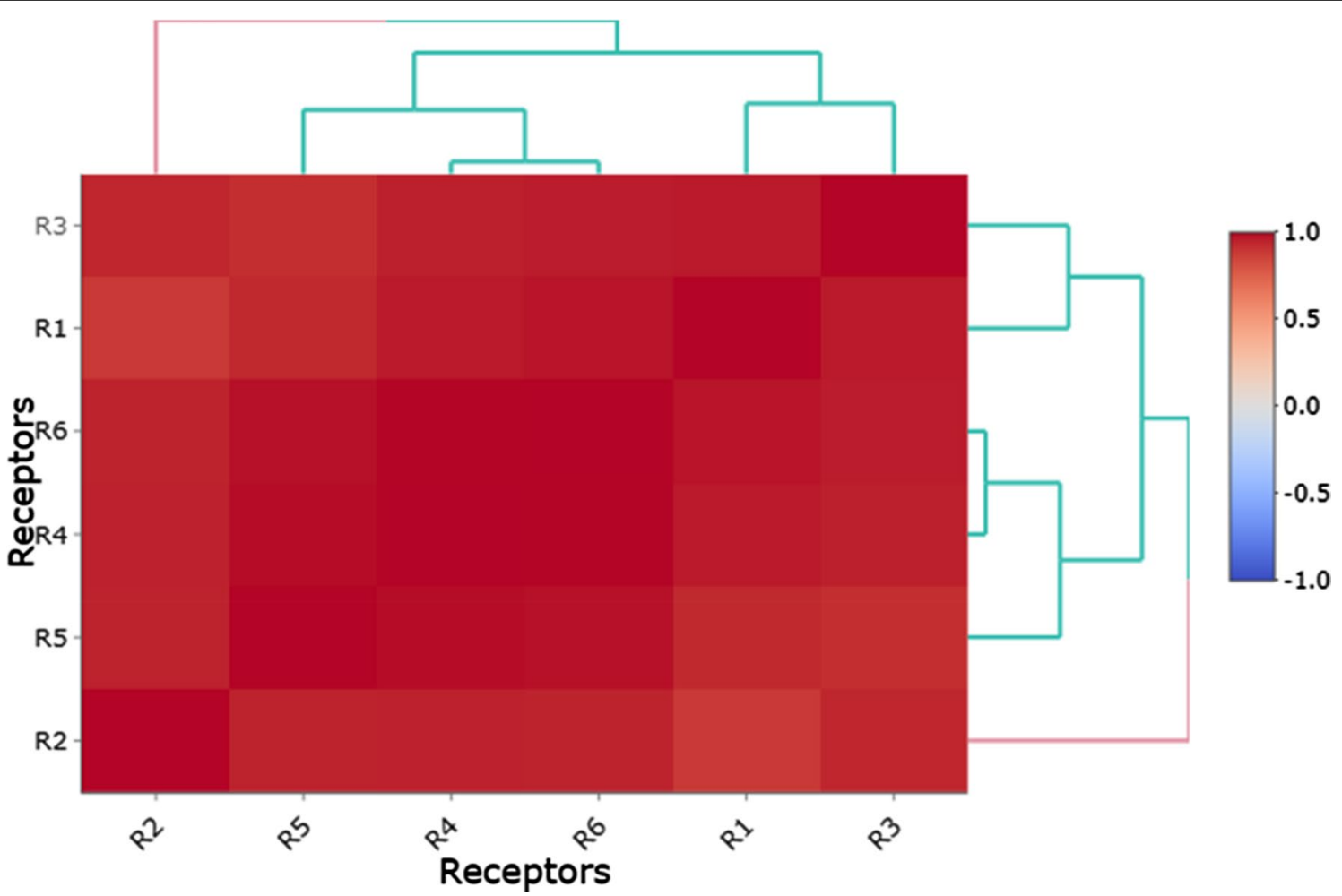

Fig. 7 Correlation of docking energies between studied active sites and affinity of their cavity to interact with target ligands. (R1=Bap1; R2= FabH; $\mathrm{R} 3=\mathrm{FtsZ} ; \mathrm{R} 4=\mathrm{MerB} ; \mathrm{R} 5=\mathrm{RbmC}$ and $\mathrm{R} 6=\mathrm{RbmA}$ )

for camphor and 1,8-cineole against all tested bacteria (Kotan et al. 2007). Well-known oxygenated monoterpenes (e.g., citral, geraniol, linalool, menthol, and thymol) as the main components of distinct essential oils, alter the permeability of the cell by penetrating through fatty acyl chains of membrane lipid bilayers, disrupt lipid packing and change the fluidity of the cell membrane (Sánchez et al. 2004).

The mechanism underlying antibiofilm activity EOs is mainly not understood well but current predictions postulated that inhibition of enzymes involved in the formation of biofilm may be supported the purposed hypotheses. According to the review of the literature, several matrix proteins including RbmA, Bap1 and $\mathrm{RbmC}$ are key factors in the development and initiation of biofilm among bacterial strains. Among these proteins, RbmA-a $26 \mathrm{kDa}$ matrix protein-displays a unique content to modulate the rugosity and structure of bacterial biofilm (Fong et al. 2006; Fong and Yildiz 2015). Mutants that have no coding sequence of RbmA gene could not produce strong and rigid biofilms; therefore, this case may indicate that the strength of bacterial biofilm is tightly depending on the regular expression of this protein (Fong et al. 2006). Additionally, the RbmA protein is involved in the formation of sessile biofilms and paly a quintessential role in the cell-cell and cell-surface interaction of bacterial community (Maestre-Reyna et al. 2013). Our docking simulation indicated that the identified metabolites among the studied plants have potential tendency to interact with crystallographic structure of biofilm matrix proteins through which may show their inhibitory profile. Among docked compounds, as detailed in result section, studied metabolites showed almost similar binding energies for hypothetical targets while cinnamaldehyde was displayed a better docking energy to interact with RbmA and $\mathrm{C}$ receptors, respectively (Figs. 6, 7).

The accumulating body of evidence reported that individual constituents of medical plants EOs are green alternatives of sodium hypochlorite and quaternary ammonium agents to prevent bacterial biofilms (Espina et al. 2015). E-Cinnamaldehyde or trans-Cinnamaldehyde was the most abundant moiety that identified within CiEO and studies reported that the antibacterial/ antibiofilm activity of CiEO is associated with this secondary metabolite (Firmino et al. 2018). One molecular mechanism that has been considered for antibacterial activity of trans-cinnamaldehyde is to interact with ESBL enzymes (Dhara and Tripathi 2013). These categories of enzymes are mainly involved in the various resistance process within bacterial cell (Dhara and Tripathi 2013). 
Nakamura et al. (2019) recently reported that ESBL protein-protein interactions may be involved in the bacterial biofilm formation, though further studies should be performed to prove this hypothesis (Nakamura et al. 2019). Indeed, other studies also reported that that antibacterial activity of cinnamaldehyde is correlated with its potential to prevent fatty acid biosynthesis within bacterial cells. In a coupled experimental/computational study, Song et al. reported that cinnamaldehyde derivatives could deter the activity of $\beta$-Ketoacyl-acyl carrier protein (ACP) synthase III enzyme that critically is involved in bacterial fatty acid biosynthesis (Song et al. 2014). In this regard, Dubois-Brissonnet et al. (2016) reported that bacterial biofilm formation is associated with an increase in bacterial membrane saturated fatty acids. Therefore, it can be concluded that $\mathrm{CiEO}$ individual components may disrupt such processes within bacterial cells to overcome the growth of infectious bacterial communities. Accordingly, our computational assay also showed that cinnamaldehyde also showed high tendency to interact with FabH active site residues. The interaction of this metabolite and FabH active site may provide extra evidence for determination of molecular mode of action of CiEO compounds against bacterial cells (Fig. 7).

By and large, $\mathrm{CaEO}$ despite of having high portion of oxygenated monoterpenes exhibited lower antibiofilm activity than CiEO. Docking results for individual constituents of these two EOs also showed that their metabolites could interact with several different bacterial targets with moderate to low binding energies. The variability of those binding energies may prove this idea that the antibacterial activity of these EOs metabolites may follow up different actions to disturb the sustainable growth of bacterial community. Because of low amount of important oxygenated monoterpenes with antibacterial activity (such as geraniol, linalool, terpinen-4-ol, $\alpha$ terpineol) in $\mathrm{CaEO}$, the lower antibiofilm property can be interpretated. All in all, the antimicrobial effects of essential oils are a result of the interaction between all components of the essential oils and no single compound effects (Delaquis and Stanich 2004; Lis-Balchin and Deans 1997; Mourey and Canillac 2002). The use of a specific EO compound alone is not effective enough for inhibition of biofilm growth (Sandasi et al. 2008). Therefore, the inhibition activity of $\mathrm{CaEO}$ on bacterial growth was probably due to the interaction of the main compounds with other oxygenated monoterpenes and the high inhibitory activity of CiEO against bacterial biofilm might be related to high amount of E-Cinnamaldehyde constituent. Therefore, such EO compounds (well-known oxygenated monoterpenes and E-Cinnamaldehyde) and $\mathrm{Ci} / \mathrm{Ca} \mathrm{EOs}$ combination might be an effective green alternative against bacterial cell attachment and biofilm formation as observed here.

\begin{abstract}
Abbreviations
CaEO: Cardamom EO; CiEO: Cinnamon EO; Ci/Ca Eos: Cinnamon and cardamom EOs; CV: Crystal violet; EO: Essential oil; GC/MS: Gas chromatographymass spectrometry; FIC: Fractional inhibitory concentration; FICI: FIC index; MIC: Minimum inhibitory concentration; MTT: (3-(4,5-Dimethyl-2-thiazolyl)2,5-diphenyl-2H tetrazolium bromide); PBS: Phosphate-buffered saline; XTT: (2,3-Bis(2-methoxy-4-nitro-5-sulfophenyl)-2H-tetrazolium-5-carboxanilide.
\end{abstract}

\section{Supplementary Information}

The online version contains supplementary material available at https://doi. org/10.1186/s13568-021-01305-6.

Additional file 1. Docking outputs for $1 \mathrm{hn} 9$ and docked ligands. Docking outputs for 2 wxy and docked compounds.

\section{Acknowledgements}

This work was conducted at Department of Agricultural Biotechnology, Imam Khomeini International University and the authors appreciate all staffs for their helpful contribution for laboratory analysis.

\section{Authors' contributions}

EPK: experimental performance. FDN and MMB: experiment design, data analysis, supervision, writing and reviewing. All authors read and approved the final manuscript.

\section{Funding}

No funding.

Availability of data and materials

The authors declare that all the data is embedded in the manuscript.

\section{Declarations}

Ethics approval and consent to participate

This study was approved by the Ethics Committee of Imam Khomeini International University (IKIU), Qazvin, Iran.

Consent for publication

All authors have approved the manuscript for publication.

Competing interests

The authors declare no competing interests.

Received: 4 October 2021 Accepted: 16 October 2021

Published online: 26 October 2021

\section{References}

Asghar A, Butt MS, Shahid M, Huang Q (2017) Evaluating the antimicrobial potential of green cardamom essential oil focusing on quorum sensing inhibition of Chromobacterium violaceum. J Food Sci Technol 54(8):2306-2315

Bazargani MM, Rohloff J (2016) Antibiofilm activity of essential oils and plant extracts against Staphylococcus aureus and Escherichia coli biofilms. Food Control 61:156-164

Borriss R, Danchin A, Harwood CR, Médigue C, Rocha EP, Sekowska A, Vallenet D (2018) Bacillus subtilis, the model Gram-positive bacterium: 20 years of annotation refinement. Microb Biotechnol 11(1):3-17

Budzyńska A, Wieckowska-Szakiel M, Sadowska B, Kalemba D, Rozalska B (2011) Antibiofilm activity of selected plant essential oils and their major components. Pol J Microbiol 60(1):35-41 
Burt S (2004) Essential oils: their antibacterial properties and potential applications in foods - a review. Int J Food Microbiol 94(3):223-253

Chaieb K, Kouidhi B, Jrah H, Mahdouani K, Bakhrouf A (2011) Antibacterial activity of Thymoquinone, an active principle of Nigella sativa and its potency to prevent bacterial biofilm formation. BMC Compl Altern Med 11(1):1-6

Chang S-T, Chen P-F, Chang S-C (2001) Antibacterial activity of leaf essential oils and their constituents from Cinnamomum osmophloeum. J Ethnopharmacol 77(1):123-127

Chemsa AE, Zellagui A, Öztürk M, Ebru E, Ceylan O, Duru ME (2018) The chemical composition of Centaurea furfuracea Coss. and Dur. essential oil with antioxidant, anticholinesterase and antibiofilm activities. J Ongo Chem Res 3(2):54-63

Chrysargyris A, Mikallou M, Petropoulos S, Tzortzakis N (2020) Profiling of essential oils components and polyphenols for their antioxidant activity of medicinal and aromatic plants grown in different environmental conditions. Agronomy 10(5):727-729

de Oliveira MMM, Brugnera DF, do Nascimento JA, Batista NN, Piccoli RH (2012) Cinnamon essential oil and cinnamaldehyde in the control of bacterial biofilms formed on stainless steel surfaces. Eur Food Res Technol 234(5):821-832

Delaquis PJ, Stanich K (2004) Antilisterial properties of cilantro essential oil. J Essent Oil Res 16(5):409-414

Dhara L, Tripathi A (2013) Antimicrobial activity of eugenol and cinnamaldehyde against extended spectrum beta lactamase producing enterobacteriaceae by in vitro and molecular docking analysis. Eur J Integr Med 5(6):527-536

Dubois-Brissonnet F, Trotier E, Briandet R (2016) The biofilm lifestyle involves an increase in bacterial membrane saturated fatty acids. Front Microbiol 7:1673-1684

Espina L, Pagán R, López D, García-Gonzalo D (2015) Individual constituents from essential oils inhibit biofilm mass production by multi-drug resistant Staphylococcus aureus. Molecules 20(6):11357-11372

Fahimi S, Hajimehdipoor H, Shabanpoor H, Bagheri F, Shekarchi M (2015) Synergic antibacterial activity of some essential oils from Lamiaceae. R.JP 2(3):23-29

Fei $L, Y-c D, X-q$ Ye, Y-t D (2011) Antibacterial effect of cinnamon oil combined with thyme or clove oil. ASC 10(9):1482-1487

Felipe V, Breser ML, Bohl LP, da Silva ER, Morgante CA, Correa SG, Porporatto C (2019) Chitosan disrupts biofilm formation and promotes biofilm eradication in Staphylococcus species isolated from bovine mastitis. Int J Biol Macromol 126:60-67

Firmino DF, Cavalcante TT, Gomes GA, Firmino N, Rosa LD, de Carvalho MG, Catunda FE Jr (2018) Antibacterial and antibiofilm activities of Cinnamomum Sp. essential oil and cinnamaldehyde: antimicrobial activities. Sci World J 2018:1-9

Fong JN, Yildiz FH (2015) Biofilm matrix proteins. Microbiol Spectr 3(2):201-222

Fong JC, Karplus K, Schoolnik GK, Yildiz FH (2006) Identification and characterization of $\mathrm{RbmA}$, a novel protein required for the development of rugose colony morphology and biofilm structure in Vibrio cholerae. J Bacteriol 188(3):1049-1059

Frozi JB, Esper LMR, Franco RM (2017) Single-and multispecies biofilms by Escherichia coli, Staphylococcus aureus, and Salmonella spp. isolated from raw fish and a fish processing unit. Cienc Rural 47(10):1-6

Gill AO, Holley RA (2004) Mechanisms of bactericidal action of cinnamaldehyde against Listeria monocytogenes and of eugenol against L. monocytogenes and Lactobacillus sakei. Appl Environ Microbiol 70(10):5750-5760

Gutierrez J, Barry-Ryan C, Bourke P (2009) Antimicrobial activity of plant essential oils using food model media: efficacy, synergistic potential and interactions with food components. Food Microbiol 26(2):142-150

Haydon DJ, Stokes NR, Ure R, Galbraith G, Bennett JM, Brown DR, Baker PJ, Barynin W, Rice DW, Sedelnikova SE (2008) An inhibitor of FtsZ with potent and selective anti-Staphylococcal activity. Science 321(5896):1673-1675

Helander IM, Alakomi H-L, Latva-Kala K, Koski P (1997) Polyethyleneimine is an effective permeabilizer of gram-negative bacteria. Microbiol 143(10):3193-3199

Helander IM, Alakomi H-L, Latva-Kala K, Mattila-Sandholm T, Pol I, Smid EJ, Gorris LG, von Wright A (1998) Characterization of the action of selected essential oil components on Gram-negative bacteria. J Agric Food Chem 46(9):3590-3595
Jamal A, Javed K, Aslam M, Jafri M (2006) Gastroprotective effect of cardamom, Elettaria cardamomum Maton. fruits in rats. J Ethnopharmacol 103(2):149-153

Kerekes EB, Vidács A, Takó M, Petkovits T, Vágvölgyi C, Horváth G, Balázs VL, Krisch J (2019) Anti-biofilm effect of selected essential oils and main components on mono-and polymicrobic bacterial cultures. Microorganisms 7(9):345-356

Kon K, Rai M (2012) Antibacterial activity of Thymus vulgaris essential oil alone and in combination with other essential oils. Nusantara Biosci 4(2):55-65

Kotan R, Kordali S, Cakir A (2007) Screening of antibacterial activities of twentyone oxygenated monoterpenes. Z Naturforsch 62(7-8):507-513

Kwieciński J, Eick S, Wójcik K (2009) Effects of tea tree (Melaleuca alternifolia) oil on Staphylococcus aureus in biofilms and stationary growth phase. Int J Antimicrob Agents 33(4):343-347

Lis-Balchin M, Deans S (1997) Bioactivity of selected plant essential oils against Listeria monocytogenes. J Appl Microbiol 82(6):759-762

Loolaie M, Moasefi N, Rasouli H, Adibi H (2017) Peppermint and its functionality: a review. Arch Clin Microbiol 8(4):54-66

LV F, Liang H, Yuan Q, Li C (2011) In vitro antimicrobial effects and mechanism of action of selected plant essential oil combinations against four foodrelated microorganisms. Food Res Int 44(9):3057-3064

Maestre-Reyna M, Wu W-J, Wang AH-J (2013) Structural insights into RbmA, a biofilm scaffolding protein of V. cholerae. PLoS ONE 8(12):e82458-e82470

Mann C, Cox S, Markham J (2000) The outer membrane of Pseudomonas aeruginosa NCTC 6749 contributes to its tolerance to the essential oil of Melaleuca alternifolia (tea tree oil). Lett Appl Microbiol 30(4):294-297

Millezi AF, Costa KAD, Oliveira JM, Lopes SP, Pereira MO, Piccoli RH (2019) Antibacterial and anti-biofilm activity of cinnamon essential oil and eugenol. Cienc Rural 49(1):1-6

Mourey A, Canillac N (2002) Anti-Listeria monocytogenes activity of essential oils components of conifers. Food Control 13(4-5):289-292

Muslim SN, Kadmy IMA, Ali ANM, Salman BK, Ahmad M, Khazaal SS, Hussein NH, Muslim SN (2018) Chitosan extracted from Aspergillus flavus shows synergistic effect, eases quorum sensing mediated virulence factors and biofilm against nosocomial pathogen Pseudomonas aeruginosa. Int J Biol Macromol 107:52-58

Nakamura A, Komatsu M, Ohno Y, Noguchi N, Kondo A, Hatano N (2019) Identification of specific protein amino acid substitutions of extended-spectrum $\beta$-lactamase (ESBL)-producing Escherichia coli ST131: a proteomics approach using mass spectrometry. Sci Rep 9(1):1-8

Nazzaro F, Fratianni F, De Martino L, Coppola R, De Feo V (2013) Effect of essential oils on pathogenic bacteria. Pharm 6(12):1451-1474

Nuryastuti T, van der Mei HC, Busscher HJ, Iravati S, Aman AT, Krom BP (2009) Effect of cinnamon oil on icaA expression and biofilm formation by Staphylococcus epidermidis. Appl Environ Microbiol 75(21):6850-6862

Oh S, Yun W, Lee J, Lee C, Kwak W, Cho J (2017) Effects of essential oil (blended and single essential oils) on anti-biofilm formation of Salmonella and Escherichia coli. J Anim Sci Technol 59(1):1-5

Ooi LS, Li Y, Kam S-L, Wang H, Wong EY, Ooi VE (2006) Antimicrobial activities of cinnamon oil and cinnamaldehyde from the Chinese medicinal herb Cinnamomum cassia Blume. AJCMB 34(03):511-522

Oral NB, Vatansever L, Aydin BD, Sezer C, Guven A, Gumez M, Kurkcuoglu M (2010) Effect of oregano essential oil on biofilms formed by Staphylococci and Escherichia coli. Kafkas Univ Vet Fak Derg 16(Suppl-A):S23-S29

Oussalah M, Caillet S, Saucier L, Lacroix M (2007) Inhibitory effects of selected plant essential oils on the growth of four pathogenic bacteria: E. coli O157: H7, Salmonella typhimurium, Staphylococcus aureus and Listeria monocytogenes. Food Control 18(5):414-420

Pandey MK, Sharma RK, Lata S (2011) Antibacterial activity of Eclipta alba (L.) Hassk. J Appl Pharm Sci 1(7):14-23

Perez-Conesa D, McLandsborough L, Weiss J (2006) Inhibition and inactivation of Listeria monocytogenes and Escherichia coli O157: H7 colony biofilms by micellar-encapsulated eugenol and carvacrol. J Food Prot 69(12):2947-2954

Pettit RK, Weber CA, Kean MJ, Hoffmann H, Pettit GR, Tan R, Franks KS, Horton ML (2005) Microplate Alamar blue assay for Staphylococcus epidermidis biofilm susceptibility testing. Antimicrob Agents Chemother 49(7):2612-2622

Pratiwi SUT, Lagendijk EL, de Weert S, Idroes R, Hertiani T, Van den Hondel C (2015) Effect of Cinnamomum burmannii Nees ex Bl. and Massoia 
aromatica Becc. Essential oils on planktonic growth and biofilm formation of Pseudomonas aeruginosa and Staphylococcus aureus in vitro. Int J Appl Res Nat Prod 8(2):1-13

Qiu X, Janson CA, Smith WW, Head M, Lonsdale J, Konstantinidis AK (2001) Refined structures of $\beta$-ketoacyl-acyl carrier protein synthase III. J Mol Biol 307(1):341-356

Rangasamy O, Raoelison G, Rakotoniriana FE, Cheuk K, Urverg-Ratsimamanga S, Quetin-Leclercq J, Gurib-Fakim A, Subratty AH (2007) Screening for anti-infective properties of several medicinal plants of the Mauritians flora. J Ethnopharmacol 109(2):331-337

Rasouli H, Mehrabi M, Arab SS, Khodarahmi R (2017) Are Pro 8/Pro 18 really critical for functional dynamic behavior of human endostatin $\mathrm{N}$-termina peptide? A comparative molecular dynamics study. J Iran Chem Soc 14(9):2023-2039

Rasouli H, Hosseini Ghazvini SMB, Yarani R, Altıntaş A, Jooneghani SGN, Ramalho TC (2020) Deciphering inhibitory activity of flavonoids against tau protein kinases: a coupled molecular docking and quantum chemical study. J Biomol Struct Dyn. https://doi.org/10.1080/07391102.2020.18148 68

Romero D, Aguilar C, Losick R, Kolter R (2010) Amyloid fibers provide structural integrity to Bacillus subtilis biofilms. PNAS 107(5):2230-2234

Ryu J-H, Beuchat LR (2005) Biofilm formation and sporulation by Bacillus cereus on a stainless steel surface and subsequent resistance of vegetative cells and spores to chlorine, chlorine dioxide, and a peroxyacetic acid-based sanitizer. J Food Prot 68(12):2614-2622

Sadiki M, Balouiri M, Barkai H, Maataoui H, Koraichi SI, Elabed S (2014) Synergistic antibacterial effect of Myrtus communis and Thymus vulgaris essential oils fractional inhibitory concentration index. Int J Pharm Pharm Sci 6:121-124

Sánchez ME, Turina AdV, Garcia DA, Nolan MV, Perillo MA (2004) Surface activity of thymol: implications for an eventual pharmacological activity. Colloids Surf B Biointerfaces 34(2):77-86

Sandasi M, Leonard C, Viljoen A (2008) The effect of five common essential oil components on Listeria monocytogenes biofilms. Food Control 19(11):1070-1075

Sandasi M, Leonard C, Viljoen A (2010) The in vitro antibiofilm activity of selected culinary herbs and medicinal plants against Listeria monocytogenes. Lett Appl Microbiol 50(1):30-35

Sarker SD, Nahar L, Kumarasamy Y (2007) Microtitre plate-based antibacterial assay incorporating resazurin as an indicator of cell growth, and its application in the in vitro antibacterial screening of phytochemicals. Methods 42(4):321-324

Semeniuc CA, Pop CR, Rotar AM (2017) Antibacterial activity and interactions of plant essential oil combinations against Gram-positive and Gramnegative bacteria. J Food Drug Anal 25(2):403-408

Silva F, Ferreira S, Queiroz JA, Domingues FC (2011) Coriander (Coriandrum sativum L.) essential oil: its antibacterial activity and mode of action evaluated by flow cytometry. J Med Microbiol 60(10):1479-1486

Singh G, Kiran S, Marimuthu P, Isidorov V, Vinogorova V (2008) Antioxidant and antimicrobial activities of essential oil and various oleoresins of Elettaria cardamomum (seeds and pods). J Sci Food Agric 88(2):280-289

Song X, Yang Y, Zhao J, Chen Y (2014) Synthesis and antibacterial activity of cinnamaldehyde acylhydrazone with a 1, 4-benzodioxan fragment as a novel class of potent $\beta$-ketoacyl-acyl carrier protein synthase III (FabH) inhibitor. Chem Pharm Bull 62(11):1110-1118

Sparkman OD (2005) Identification of essential oil components by gas chromatography/quadrupole mass spectroscopy Robert P Adams. J Am Soc Mass Spectrom 16(11):1902-1910

Stojković D, Glamočlija J, Ćirić A, Nikolić M, Ristić M, Šiljegović J, Soković M (2013) Investigation on antibacterial synergism of Origanum vulgare and Thymus vulgaris essential oils. Arch Biol Sci 65(2):639-643

Trombetta D, Castelli F, Sarpietro MG, Venuti V, Cristani M, Daniele C, Saija A, Mazzanti G, Bisignano G (2005) Mechanisms of antibacterial action of three monoterpenes. Antimicrob Agents Chemother 49(6):2474-2486

Wang Z, Yang Q, Wang X, Li R, Qiao H, Ma P, Sun Q, Zhang H (2020) Antibacterial activity of xanthan-oligosaccharide against Staphylococcus aureus via targeting biofilm and cell membrane. Int J Biol Macromol 153:539-544

Zarayneh S, Sepahi AA, Jonoobi M, Rasouli H (2018) Comparative antibacterial effects of cellulose nanofiber, chitosan nanofiber, chitosan/cellulose combination and chitosan alone against bacterial contamination of Iranian banknotes. Int J Biol Macromol 118:1045-1054

Zhang Y, Kong J, Xie Y, Guo Y, Cheng Y, Qian H, Yao W (2018) Essential oil components inhibit biofilm formation in Erwinia carotovora and Pseudomonas fluorescens via anti-quorum sensing activity. LWT 92:133-139

\section{Publisher's Note}

Springer Nature remains neutral with regard to jurisdictional claims in published maps and institutional affiliations.

\section{Submit your manuscript to a SpringerOpen ${ }^{\circ}$ journal and benefit from:}

- Convenient online submission

- Rigorous peer review

- Open access: articles freely available online

- High visibility within the field

Retaining the copyright to your article

Submit your next manuscript at springeropen.com 